\title{
Article \\ Catalytic Antioxidant Activity of Bis-Aniline-Derived Diselenides as GPx Mimics
}

\author{
Giancarlo V. Botteselle ${ }^{1, *}$, Welman C. Elias ${ }^{2}$, Luana Bettanin ${ }^{2}$, Rômulo F. S. Canto ${ }^{3}$, Drielly N. O. Salin ${ }^{2}$, \\ Flavio A. R. Barbosa ${ }^{2}$, Sumbal Saba ${ }^{4}$, Hugo Gallardo ${ }^{2}$, Gianluca Ciancaleoni ${ }^{5}$ (D) Josiel B. Domingos 2 , \\ Jamal Rafique ${ }^{6, *(\mathbb{D})}$ and Antonio L. Braga $2,7, * \mathbb{D}$
}

check for updates

Citation: Botteselle, G.V.; Elias, W.C.; Bettanin, L.; Canto, R.F.S.; Salin, D.N.O.; Barbosa, F.A.R.; Saba, S.; Gallardo, H.; Ciancaleoni, G.; Domingos, J.B.; et al. Catalytic Antioxidant Activity of Bis-Aniline-Derived Diselenides as GPx Mimics. Molecules 2021, 26, 4446. https://doi.org/10.3390/ molecules26154446

Academic Editor: Luana Bagnoli

Received: 23 June 2021

Accepted: 20 July 2021

Published: 23 July 2021

Publisher's Note: MDPI stays neutral with regard to jurisdictional claims in published maps and institutional affiliations.

Copyright: (c) 2021 by the authors. Licensee MDPI, Basel, Switzerland. This article is an open access article distributed under the terms and conditions of the Creative Commons Attribution (CC BY) license (https:/ / creativecommons.org/licenses/by/ $4.0 /)$.
1 Departamento de Química, Universidade Estadual do Centro-Oeste (UNICENTRO), Guarapuava 85040-167, PR, Brazil

2 Departamento de Química, Universidade Federal de Santa Catarina (UFSC), Florianópolis 88040-970, SC, Brazil; welmanqmc@gmail.com (W.C.E.); luana_bettanin@hotmail.com (L.B.); driellyolek@gmail.com (D.N.O.S.); flavioauggusto@gmail.com (F.A.R.B.); hugo.gallardo@ufsc.br (H.G.); josiel.domingos@ufsc.br (J.B.D.)

3 Programa de Pós-Graduação em Ciências da Saúde, Universidade Federal de Ciências da Saúde de Porto Alegre (UFCSPA), Porto Alegre 90050-170, RS, Brazil; rfscanto@gmail.com

4 Instituto de Química-IQ, Universidade Federal de Goiás—(UFG), Goiânia 74690-900, GO, Brazil; sumbalsaba@ufg.br

5 Department of Chemistry and Industrial Chemistry, University of Pisa, Via G. Moruzzi 13, I-56124 Pisa, Italy; gianluca.ciancaleoni@unipi.it

6 Instituto de Química-INQUI, Universidade Federal do Mato Grosso do Sul (UFMS), Campo Grande 79074-460, MS, Brazil

7 Department of Chemical Sciences, Faculty of Science, University of Johannesburg, Doornfontein 2028, South Africa

* Correspondence: giancarlo@unicentro.br (G.V.B.); jamal.chm@gmail.com (J.R.); braga.antonio@ufsc.br (A.L.B.)

Abstract: Herein, we describe a simple and efficient route to access aniline-derived diselenides and evaluate their antioxidant/GPx-mimetic properties. The diselenides were obtained in good yields via ipso-substitution/reduction from the readily available 2-nitroaromatic halides $(\mathrm{Cl}, \mathrm{Br}, \mathrm{I})$. These diselenides present GPx-mimetic properties, showing better antioxidant activity than the standard GPx-mimetic compounds, ebselen and diphenyl diselenide. DFT analysis demonstrated that the electronic properties of the substituents determine the charge delocalization and the partial charge on selenium, which correlate with the catalytic performances. The amino group concurs in the stabilization of the selenolate intermediate through a hydrogen bond with the selenium.

Keywords: organoselenides; GPx; DFT; non-bonding interaction; diselenides; anilines

\section{Introduction}

In recent years, there has been an increasing interest in synthetic organoselenium compounds, mainly due to their properties as synthetic intermediates in organic transformations [1-3] and material sciences [4,5], as well as in medicinal chemistry [6-9]. These compounds have been recently described as good antioxidants [10,11], also presenting anti-inflammatory [12,13], antibacterial [14], antiviral [15], anticancer [16-19], anti-Alzheimer's [20-23] and other activities [24-28]. Furthermore, in relation to the current pandemic of COVID-19, there are some interesting studies available that demonstrate the effectiveness of organoselenium compound (Ebselen) as an antiviral molecule, Figure 1 [29-31]. 
<smiles>O=c1c2ccccc2[se]n1-c1ccccc1</smiles>

Figure 1. Ebselen.

Among organoselenium compounds, diorganyl diselenides present important antioxidant and anticancer properties mainly because of the ability of these diselenides to act as mimetics of the enzyme glutathione peroxidase (GPx) $[6,8,11]$. This selenoenzyme possesses a residue of selenocysteine in its active site and is responsible for the reduction of peroxides to water in our organism, protecting it from oxidative stress and related diseases [32].

Notable among the polyfunctionalized diselenides, the presence of an amino or carbonyl group in close proximity to the selenium moiety has some unique biological features due to non-bonding interactions [33-35]. For example, the bis-2-aniline diselenide is reported to be a good antioxidant, preventing the oxidative stress caused by peroxynitrite and hydroperoxides [36-38]. Moreover, the aniline-derived diselenides, mainly with an amino group in the ortho position, give these compounds two possible reactive centers, Se-Se bond cleavage and the unshared pair of electrons on the nitrogen. This makes this class of compounds extremely flexible in functional group interconversions, making it appropriate for several transformations, mainly in the formation of selenium-containing heterocycles, such as selenamides [39], benzoselenazines [40], benzoselenazoles [41] and triazole diselenides [42].

Recently, we reported a new robust methodology for the synthesis of $o$-aniline-derived diselenides from the reduction of $o$-nitrobenzene diselenides. As part of our wider research program aimed at efficient methodologies for the synthesis of organoselenium compounds and their biological evaluation [43-50], herein, we report the application of 0 -anilinederived diselenides as potential GPx mimics. For this purpose, different physical-chemical studies were performed to demonstrate their biological properties, i.e., kinetic profile. Furthermore, DFT studies were also carried out in order to study the electronic properties of the substituents for determining the charge delocalization on the selenium atom and its influence on catalytic performance.

\section{Results and Discussion}

The bis-o-nitrobenzene diselenides were initially prepared through the nucleophilic aromatic substitution of $o$-halonitrobenzenes with $\mathrm{K}_{2} \mathrm{Se}_{2}$ (generated in situ) from a modified simple methodology [51]. After this, we carried out the reduction of bis- $O$-nitrobenzene diselenides from a well-established procedure described in the literature [52] using lowcost iron sulfate heptahydrate $\left(\mathrm{FeSO}_{4} \cdot 7 \mathrm{H}_{2} \mathrm{O}\right)$ to synthesize the aniline-derived diselenides (Scheme 1).

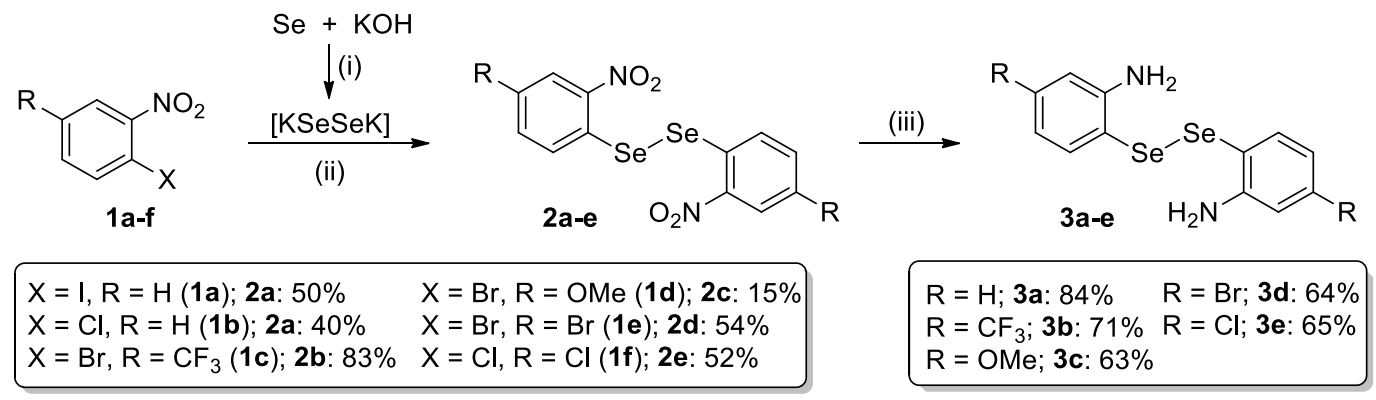

Scheme 1. Reaction conditions: (i) Se ( $3.0 \mathrm{mmol}), \mathrm{KOH}(6.0 \mathrm{mmol})$, heated until melted for $5 \mathrm{~min}$ and $\mathrm{H}_{2} \mathrm{O}(6.0 \mathrm{~mL})$; (ii) $o$-halonitrobenzene $\mathbf{1 a}-\mathbf{f}(1.5 \mathrm{mmol})$ and THF or DMF $(1.5 \mathrm{~mL})$, r.t., $2 \mathrm{~h}$; (iii) bis-nitrobenzene diselenide $2 \mathbf{a}-\mathbf{e}(1.5 \mathrm{mmol})$ and $\mathrm{FeSO}_{4} .7 \mathrm{H}_{2} \mathrm{O}(5.0 \mathrm{eq})$, methanol $(25.0 \mathrm{~mL})$ and $\mathrm{H}_{2} \mathrm{O}(25.0 \mathrm{~mL})$, reflux, $1 \mathrm{~h}$. $\mathrm{NH}_{4} \mathrm{OH}(15.0 \mathrm{~mL})$, reflux, $10 \mathrm{~min}$. 
The aniline-derived diselenides 3a-e were evaluated with regard to GPx-like antioxidant activity. The catalytic parameters were obtained using the Tomoda [53] reaction model, where the synthesized diselenides were applied as catalysts in the formation of diphenyl disulfide (PhSSPh) through the reduction of hydrogen peroxide $\left(\mathrm{H}_{2} \mathrm{O}_{2}\right)$ in the presence of thiophenol (PhSH), which is accompanied by an increase in UV/vis absorbance in $305 \mathrm{~nm}$ (Figure 2a). Then, the absorbance was plotted against diphenyl disulfide concentration to determine the molar absorptivity at $305 \mathrm{~nm}$ (Figure 2b).
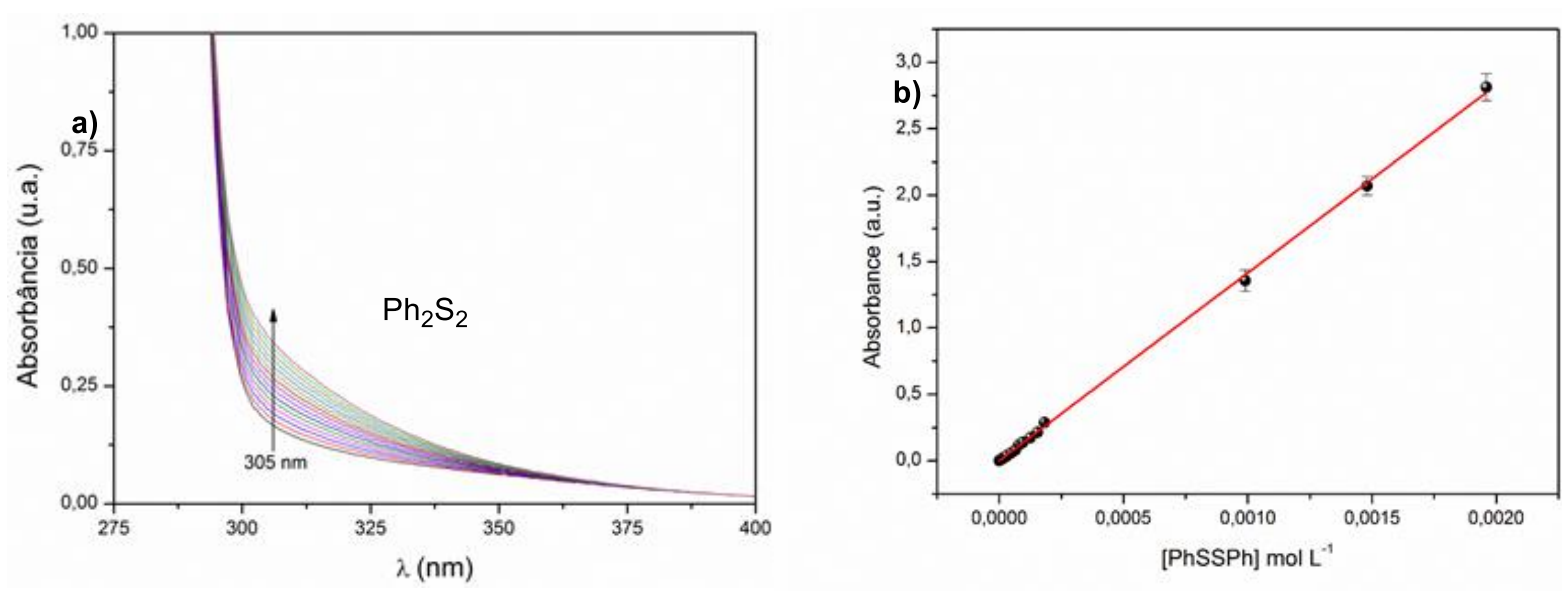

Figure 2. (a) UV-Vis spectrum of $\mathrm{PhSH}$ oxidation in the presence of $\mathrm{H}_{2} \mathrm{O}_{2}$ and diselenide $3 \mathbf{b}$ as catalyst. $[\mathrm{PhSH}]=10 \mathrm{mmol} \mathrm{L}^{-1},[3 \mathbf{b}]=0.01 \mathrm{mmol} \mathrm{L}^{-1}$ and $\left[\mathrm{H}_{2} \mathrm{O}_{2}\right]=15 \mathrm{mmol} \mathrm{L}{ }^{-1}$, in methanol at $25^{\circ} \mathrm{C}$; (b) Absorbance plotted against diphenyl disulfide concentration. The red line represents the linear fit. The coefficient of molar absorptivity in $305 \mathrm{~nm}$ was $1415 \mathrm{~L} \mathrm{~mol}^{-1} \mathrm{~cm}^{-1}\left(\mathrm{R}^{2}=0.9996\right)$.

The catalytic parameters were obtained by fitting the kinetic profiles, that is, initial rate versus initial PhSH concentration, as shown in Figure 3 for diselenide $\mathbf{3 b}$ (for other compounds, see Figures S31-S38, Pg. S22-S25 in Supplementary Materials), with the Michaelis-Menten equation (Equation (1)).

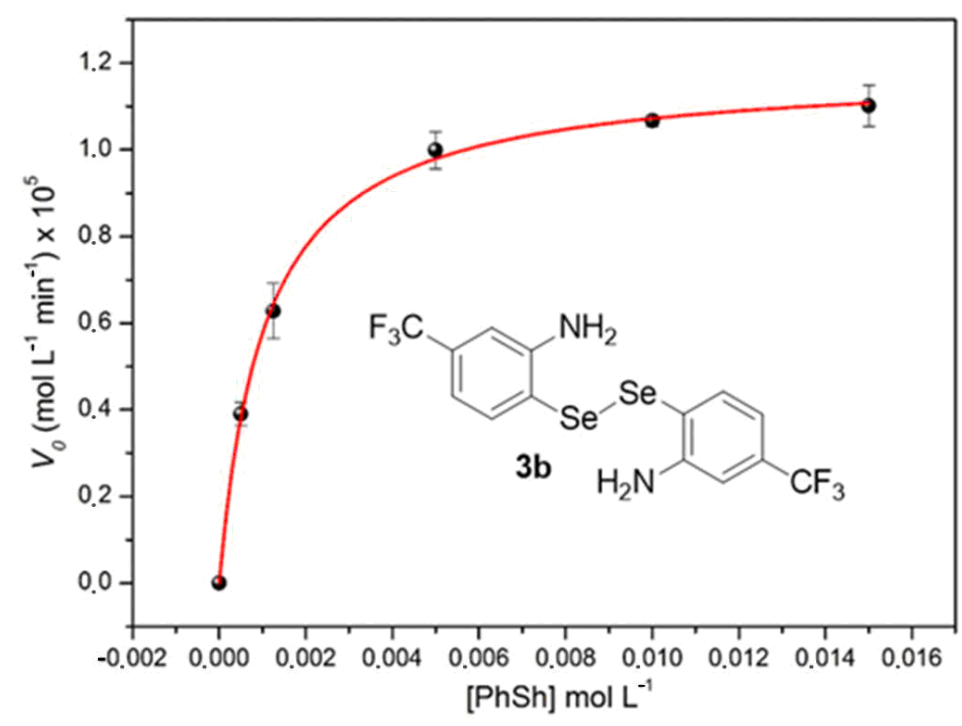

Figure 3. Initial rate $\left(V_{0}\right)$ plotted against substrate concentration. The initial rates were calculated from at least two experiments for each concentration of $\mathrm{PhSH}$. The concentrations of $\mathbf{3 b}$ and $\mathrm{H}_{2} \mathrm{O}_{2}$ were fixed at $1 \times 10^{-5}$ and $15 \times 10^{-3} \mathrm{~mol} \mathrm{~L}^{-1}$, respectively. The red line represents the MichaelisMenten fit. 
Table 1 shows the catalytic constant $\left(k_{c a t}\right)$, the Michaelis-Menten constant $\left(K_{m}\right)$ and the catalytic efficiency $\left(\eta\right.$ where $\left.\eta=k_{c a t} / K_{m}\right)$ for the reaction with the aniline-derived diselenides $\mathbf{3 a}$ to $\mathbf{3 e}$ and, for comparison, the well-known catalysts ebselen [35] and diphenyl diselenide [53].

Table 1. GPx-like catalytic evaluation of aniline-derived diselenides 3a-e.

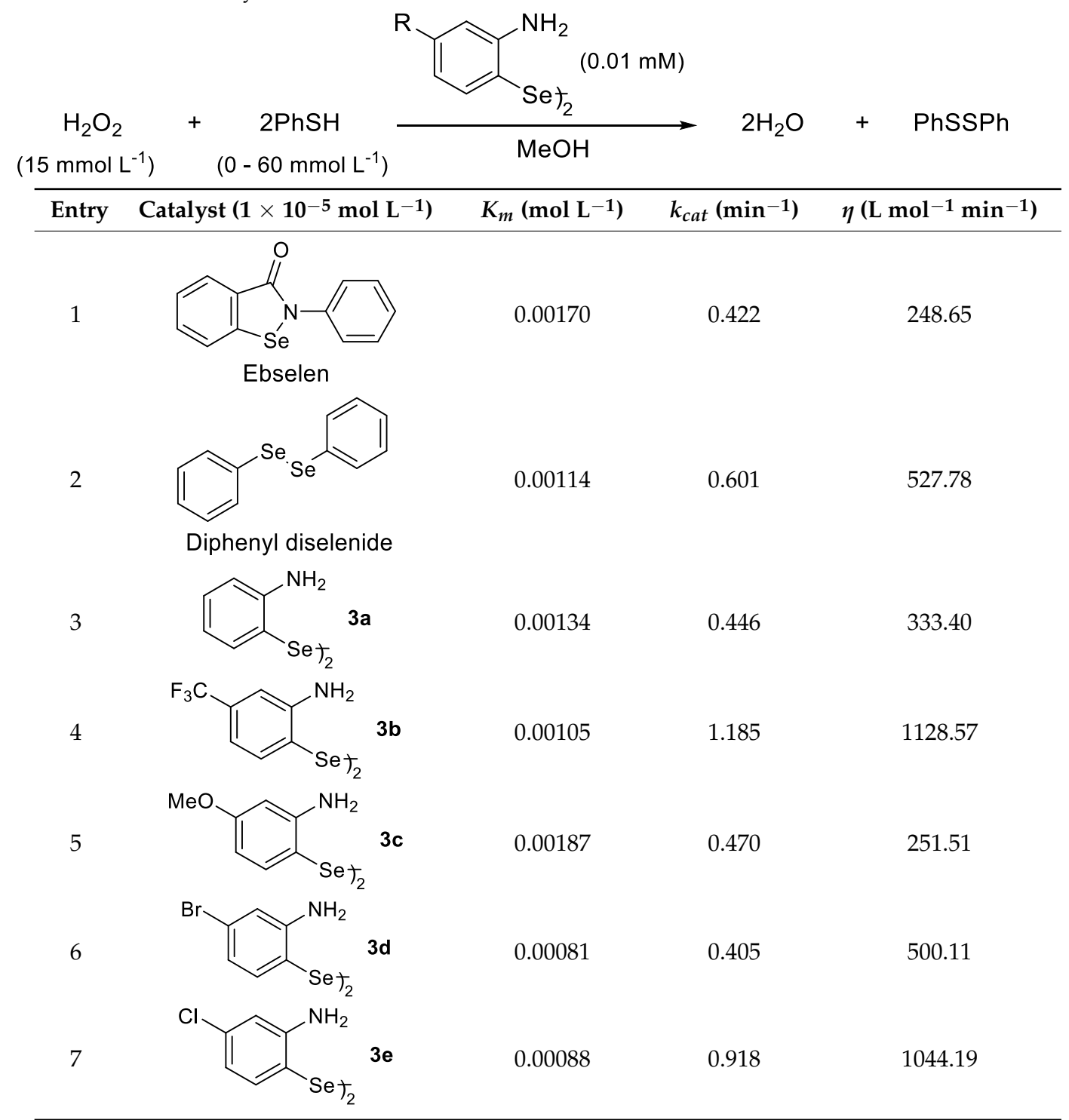

The results show that the catalytic efficiency of the aniline-derived diselenides is structure-dependent, especially regarding the electronic character of the substituents at the para position related to selenium, with an increase in the catalytic efficiency with the electron-withdrawal capacity of the substituent (compound $3 \mathbf{b}$ ), once cleavage of the Se-Se bond is facilitated. These results suggest that the mechanism of these catalyzed reactions involves the formation of a zwitterionic form of the selenolate intermediate with a negative density charge in the selenium atom (Scheme 2a), which is similar to the mechanism proposed by Tomoda et al. [53]. 
(a)<smiles>[R]c1ccc2c(c1)[NH2+][CH-][SeH]2</smiles>

(b)<smiles>[R]c1ccc([Se][SbH])c(N)c1</smiles>

Scheme 2. Reactive intermediates: (a) selenolate (a-e) and (b) selenyl sulfide.

The structures 3a-e have been optimized by Density Functional Theory (DFT) at the BP86-D3/def2-TZVP level of theory, using the zero-order regular approximation (ZORA) to take the relativistic effects into account. In all the optimized geometries (except $\mathbf{3 b}$ ), an intramolecular hydrogen bond (HB) exists between the two amine moieties, with distances that range from 2.624 (3d) to 3.139 (3a) $\AA$. In the case of $3 \mathbf{b}$, the electron-withdrawing $-\mathrm{CF}_{3}$ group likely makes the lone pair of the nitrogen less available for HBs. The electronic effect of the group in the para position influences all the atomic charges of the diselenide system. Indeed, the atomic charges have been computed through the Natural Population Analysis (see Computational Details) as implemented in NBO 6.0, and for the selenium, it ranges from 0.063 to 0.123 e for $3 \mathrm{c}$ (the most electron-donating group) and $\mathbf{3 b}$ (the most electron-withdrawing one), respectively. The atomic charge on the selenium qualitatively correlates with $\eta$, according to which the best catalysts have a more positive charge on the selenium and a less negative charge on the nitrogen (Figure 4 and Supplementary Materials). In addition, a similar correlation can be observed between the atomic charge of the ammonium-selenolate and $\eta$ : in this case, the best catalysts have a less negative charge on the selenium, leading to a larger degree of charge delocalization and, consequently, a more stable intermediate. This is in agreement with the mechanism proposed by Tomoda [53]. Furthermore, the hydrogen bonding between the ammonium protons and the selenolate moiety is quite strong and stabilizes the intermediate, having an orbital interaction of 8-9 kcal/mol depending on the substituent (Supplementary Materials), hence making the catalyst more active.

Tomoda et al. [53] also proposed that another reactive intermediate is formed in the initial step from the reaction of the diselenide with $\mathrm{PhSH}$, that is, the selenyl sulfide (Scheme $2 b$ ). In the case of the aniline-derived diselenides, it seems that the formation of this intermediate is destabilized by the inductive electron donor capacity of the amine groups at the ortho position, reflected in their lower catalytic efficiency when compared with the diphenyl diselenide (Table 1, entries 3 and 2, respectively).

Of the aniline-derived diselenides, the highest catalytic efficiency was observed for compound $\mathbf{3 b}$ (Table 1 , entry 4 ), which was 5 and 2 times more active than the standards ebselen and diphenyl diselenide, respectively. It is worth noting that the diselenide $\mathbf{3 b}$ was more effective than ebselen, which is a pre-clinical drug candidate with pronounced biological activities, including, recently, the inhibition of protease $\mathrm{M}^{\text {pro }}$ from COVID-19 (SARS-CoV-2) virus [29-31].

Due to the high antioxidant activity of the diselenide $3 \mathbf{b}$ as a mimetic of GPx, we decided to investigate the effectiveness of this methodology at the gram scale. Thus, we performed the reaction from $20.0 \mathrm{mmol}(5.40 \mathrm{~g})$ of the o-halonitrobenzene $1 \mathrm{c}$ to afford the desired nitro-diselenide $\mathbf{2} \mathbf{b}$, followed by its reduction to obtain the bis-aniline-derived $\mathbf{3 b}$ without a significant decrease in the yields (Scheme 3), proving that this protocol could be used as a robust method in the larger-scale synthesis of this privileged structure. 

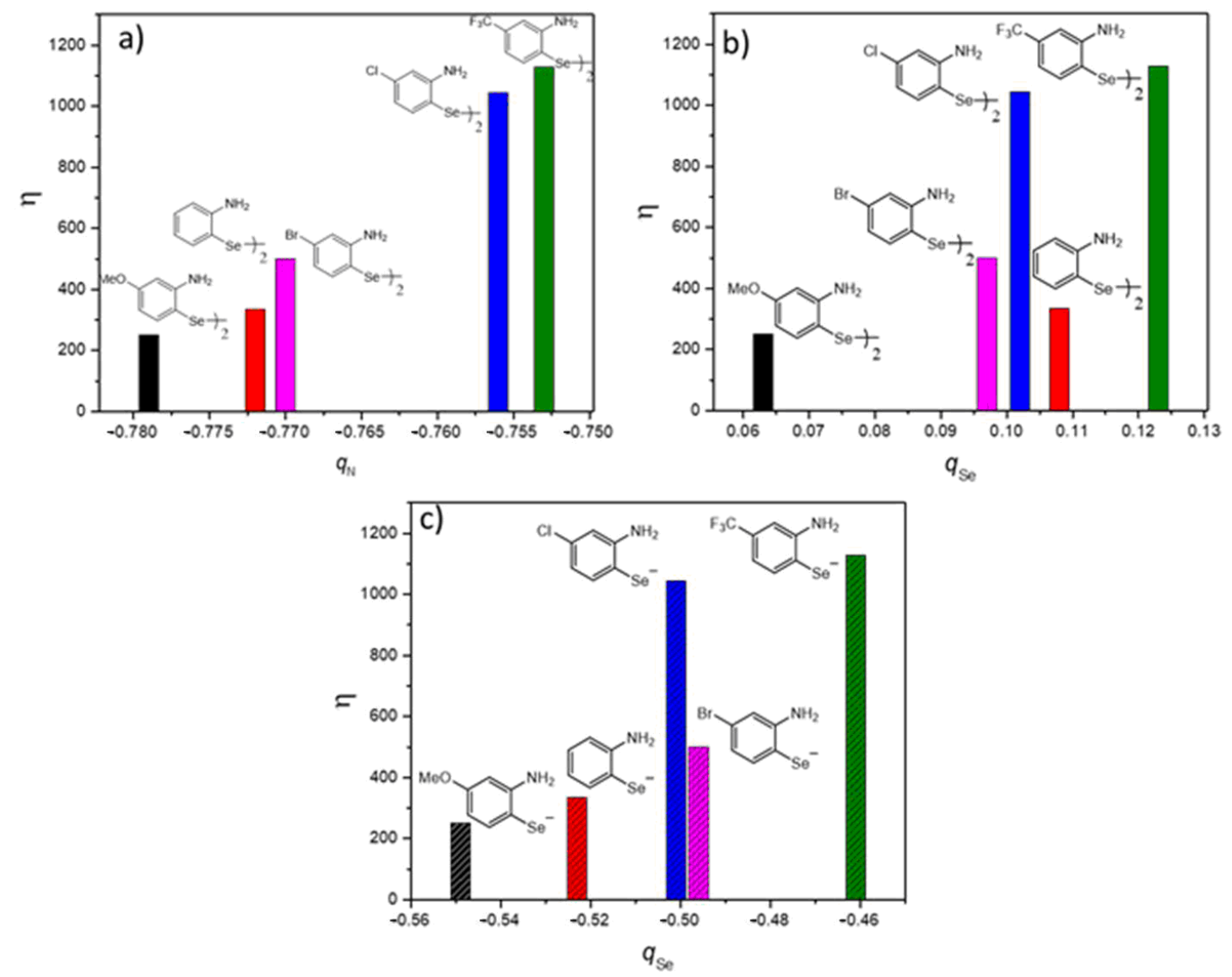

Figure 4. Catalytic efficiency $(\eta)$ plotted against calculated atomic charges for (a) N atom $\left(q_{\mathrm{N}}\right)$ of aniline-derived diselenides, (b) Se atom $\left(q_{\mathrm{Se}}\right)$ of aniline-derived diselenides, and (c) Se atom $\left(q_{\mathrm{Se}}\right)$ of aniline-derived selenolates.

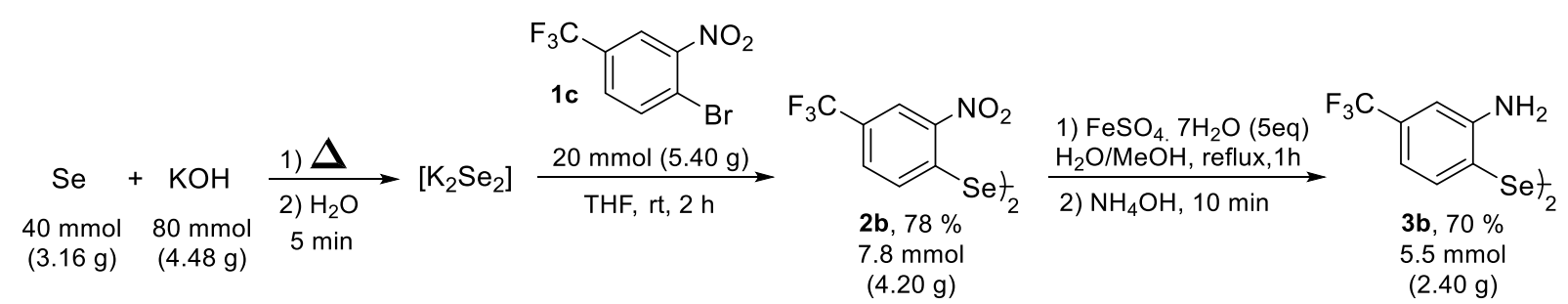

Scheme 3. Gram-scale reaction for the synthesis of aniline-derived diselenide $\mathbf{3 b}$.

\section{Materials and Methods}

\subsection{GPx-Like Experimental Procedure}

The kinetic profile of the oxidation reaction was conducted in a UV-vis Spectrophotometer, following the wavelength of diphenyl disulfide formation at $305 \mathrm{~nm}$. Spectroscopic methanol was used as solvent in the oxidation reaction, and the final volume of cuvettes was kept at $2000 \mu \mathrm{L}$. The $\mathrm{H}_{2} \mathrm{O}_{2}$ and catalyst concentration were fixed in $15 \times 10^{-3} \mathrm{~mol} \mathrm{~L}^{-1}$ and $1 \times 10^{-5} \mathrm{~mol} \mathrm{~L}^{-1}$ respectively, and the $\mathrm{PhSH}$ concentration was varied from $0.5 \times 10^{-3}$ to $15 \times 10^{-3} \mathrm{~mol} \mathrm{~L}^{-1}$. The temperature was kept at $25^{\circ} \mathrm{C}$, and each experiment was run at least 2 times.

\subsection{Michaelis-Menten Equation}

The GPx-like kinetic profiles were treated using the Michaelis-Menten nonlinear Equation (1):

$$
V=\frac{k_{c a t}[\mathrm{cat}][\mathrm{PhSH}]}{\left(K_{m}+[\mathrm{PhSH}]\right)}
$$


where the $V_{0}$ was the initial velocity and $k_{\text {cat }}$ and $K_{m}$ were the catalytic rate constant and Michaelis-Menten constant, respectively. The [cat $]$ and $[\mathrm{PhSH}]$ represent the concentration of the catalyst and thiophenol, respectively.

\subsection{Computational Details}

All geometries were optimized with ORCA 4.1.0, [54] using the BP86 functional in conjunction with a triple- $\zeta$ quality basis set (ZORA-TZVP) and def $2 / \mathrm{J}$ auxiliary basis. For heavy elements (such as selenium and bromine), relativistic effects have been accounted by using the Zeroth Order Regular Approximation (ZORA) scalar correction. The dispersion corrections were introduced using the Grimme D3-parametrized correction and the Becke-Johnson damping to the DFT energy [55]. All the diselenide structures were confirmed to be local energy minima (no imaginary frequencies). Selenolate species show an unavoidable imaginary frequency correlated with the rotation of the $-\mathrm{NH}_{3}$ moiety. The atomic charges have been computed by the Natural Population Analysis (NPA) as implemented in NBO6 [56].

\section{Conclusions}

In conclusion, we have developed a short and robust synthetic route for the synthesis of nitro aryl and aniline-derived diselenides in good overall yields. The aniline-derived diselenides were evaluated as GPx mimetics and the diselenide $\mathbf{3 b}$ substituted with the $\mathrm{CF}_{3}$ group showed the best results, being 5 and 2 times more effective as a GPx mimetic than the standard catalysts ebselen and diphenyl diselenide, respectively. Furthermore, DFT analysis was performed for all the diselenides, which demonstrated non-bonding interaction. This correlates with the GPx activities of these diselenides.

Supplementary Materials: The following are available online, ${ }^{1} \mathrm{H}$, and ${ }^{13} \mathrm{C}$ NMR spectra of the synthesized compounds (3a-e). Figure S1: ${ }^{1} \mathrm{H}$ NMR (200 MHz, $\mathrm{CDCl}_{3}$ ) Spectrum of compound 2a. Figure S2: ${ }^{13} \mathrm{C}$ NMR $\left(50 \mathrm{MHz}, \mathrm{CDCl}_{3}\right)$ Spectrum of compound 2a. Figure S3: HRMS spectrum of compound 2a. Figure S4: ${ }^{1} \mathrm{H}$ NMR $\left(200 \mathrm{MHz}, \mathrm{CDCl}_{3}\right)$ Spectrum of compound 2b. Figure S5: ${ }^{13} \mathrm{C}$ $\mathrm{NMR}\left(50 \mathrm{MHz}, \mathrm{CDCl}_{3}\right.$ ) Spectrum of compound $\mathbf{2 b}$. Figure S6: HRMS spectrum of compound $\mathbf{2 b}$. Figure S7: ${ }^{1} \mathrm{H}$ NMR $\left(200 \mathrm{MHz}, \mathrm{CDCl}_{3}\right)$ Spectrum of compound 2c. Figure S8: ${ }^{13} \mathrm{C} \mathrm{NMR}(50 \mathrm{MHz}$, $\mathrm{CDCl}_{3}$ ) Spectrum of compound 2c. Figure S9: HRMS spectrum of compound 2c. Figure S10: ${ }^{1} \mathrm{H}$ NMR $\left(200 \mathrm{MHz}, \mathrm{CDCl}_{3}\right)$ Spectrum of compound 2d. Figure S11: ${ }^{13} \mathrm{C} \mathrm{NMR}\left(50 \mathrm{MHz}, \mathrm{CDCl}_{3}\right)$ Spectrum of compound 2d. Figure S12: HRMS spectrum of compound 2d. Figure S13: ${ }^{1} \mathrm{H}$ NMR $(200 \mathrm{MHz}$, $\left.\mathrm{CDCl}_{3}\right)$ Spectrum of compound 2e. Figure S14: ${ }^{13} \mathrm{C} \mathrm{NMR}\left(50 \mathrm{MHz}, \mathrm{CDCl}_{3}\right)$ Spectrum of compound 2e. Figure S15: ESI-MS spectrum of compound 2e. Figure S16: ${ }^{1} \mathrm{H}$ NMR $\left(200 \mathrm{MHz}, \mathrm{CDCl}_{3}\right)$ Spectrum of compound 3a. Figure S17: ${ }^{13} \mathrm{C} \mathrm{NMR}\left(50 \mathrm{MHz}_{\mathrm{CDCl}}\right)$ Spectrum of compound 3a. Figure S18: ${ }^{1} \mathrm{H} \mathrm{NMR}\left(200 \mathrm{MHz}, \mathrm{CDCl}_{3}\right)$ Spectrum of compound $3 \mathbf{b}$. Figure S19: ${ }^{13} \mathrm{C} \mathrm{NMR}\left(50 \mathrm{MHz}, \mathrm{CDCl}_{3}\right)$ Spectrum of compound $3 \mathbf{b}$. Figure S20: HRMS spectrum of compound $3 \mathbf{b}$. Figure S21: ${ }^{1} \mathrm{H}$ NMR $\left(200 \mathrm{MHz}, \mathrm{CDCl}_{3}\right)$ Spectrum of compound 3c. Figure S22: ${ }^{13} \mathrm{C} \mathrm{NMR}\left(50 \mathrm{MHz}, \mathrm{CDCl}_{3}\right)$ Spectrum of compound 3c. Figure S23: HRMS spectrum of compound 3c. Figure S24: ${ }^{1} \mathrm{H}$ NMR $(200 \mathrm{MHz}$, $\left.\mathrm{CDCl}_{3}\right)$ Spectrum of compound 3d. Figure S25: ${ }^{13} \mathrm{C} \mathrm{NMR}\left(50 \mathrm{MHz}, \mathrm{CDCl}_{3}\right)$ Spectrum of compound 3d. Figure S26: HRMS spectrum of compound 3d. Figure S27: ${ }^{1} \mathrm{H}$ NMR $\left(200 \mathrm{MHz}, \mathrm{CDCl}_{3}\right)$ Spectrum of compound 3e. Figure S28: ${ }^{13} \mathrm{C}$ NMR $\left(50 \mathrm{MHz}_{\mathrm{CDCl}}\right)$ Spectrum of compound 3e. Figure S29: ESI-MS spectrum of compound 3e. Figure S30: ${ }^{77} \mathrm{Se} \mathrm{NMR}\left(76 \mathrm{MHz}, \mathrm{CDCl}_{3}\right)$ Spectrum of compound 3b. Figure S31: Absorbance plotted against diphenyl disulfide concentration. The red line represents the linear fit. The coefficient of molar absorptivity in $305 \mathrm{~nm}$ was $1415 \mathrm{~L} \mathrm{~mol}^{-1} \mathrm{~cm}^{-1}\left(\mathrm{R}^{2}=0.9996\right)$. Figure S32: Initial rate $\left(V_{0}\right)$ plotted against substrate concentration. The initial rates were calculated from at least two experiments for each concentration of PhSH. The concentrations of ebselen and $\mathrm{H}_{2} \mathrm{O}_{2}$ were fixed at $5 \times 10^{-5}$ and $15 \times 10^{-3} \mathrm{~mol} \mathrm{~L}^{-1}$, respectively. The red line represents the Michaelis-Menten fit. Figure S33: Initial rate $\left(V_{0}\right)$ plotted against substrate concentration. The initial rates were calculated from at least two experiments for each concentration of $\mathrm{PhSH}$. The concentrations of diphenyl disulfide and $\mathrm{H}_{2} \mathrm{O}_{2}$ were fixed at $5 \times 10^{-5}$ and $15 \times 10^{-3} \mathrm{~mol} \mathrm{~L}^{-1}$, respectively. The red line represents the Michaelis-Menten fit. Figure S34: Initial rate $\left(V_{0}\right)$ plotted against substrate concentration. The initial rates were calculated from at least two experiments for each concentration of PhSH. The concentrations of $3 \mathrm{c}$ and $\mathrm{H}_{2} \mathrm{O}_{2}$ were fixed at $5 \times 10^{-5}$ and 
$15 \times 10^{-3} \mathrm{~mol} \mathrm{~L}^{-1}$, respectively. The red line represents the Michaelis-Menten fit. Figure S35: Initial rate $\left(V_{0}\right)$ plotted against substrate concentration. The initial rates were calculated from at least two experiments for each concentration of PhSH. The concentrations of $3 \mathbf{a}$ and $\mathrm{H}_{2} \mathrm{O}_{2}$ were fixed at $5 \times 10^{-5}$ and $15 \times 10^{-3} \mathrm{~mol} \mathrm{~L}^{-1}$, respectively. The red line represents the Michaelis-Menten fit. Figure S36: Initial rate $\left(V_{0}\right)$ plotted against substrate concentration. The initial rates were calculated from at least two experiments for each concentration of $\mathrm{PhSH}$. The concentrations of $3 \mathbf{b}$ and $\mathrm{H}_{2} \mathrm{O}_{2}$ were fixed at $5 \times 10^{-5}$ and $15 \times 10^{-3} \mathrm{~mol} \mathrm{~L}^{-1}$, respectively. The red line represents the MichaelisMenten fit. Figure S37: Initial rate $\left(V_{0}\right)$ plotted against substrate concentration. The initial rates were calculated from at least two experiments for each concentration of $\mathrm{PhSH}$. The concentrations of $3 \mathrm{~d}$ and $\mathrm{H}_{2} \mathrm{O}_{2}$ were fixed at $5 \times 10^{-5}$ and $15 \times 10^{-3} \mathrm{~mol} \mathrm{~L}^{-1}$, respectively. The red line represents the Michaelis-Menten fit. Figure S38: Initial rate $\left(V_{0}\right)$ plotted against substrate concentration. The initial rates were calculated from at least two experiments for each concentration of $\mathrm{PhSH}$. The concentrations of $3 \mathbf{e}$ and $\mathrm{H}_{2} \mathrm{O}_{2}$ were fixed at $5 \times 10^{-5}$ and $15 \times 10^{-3} \mathrm{~mol} \mathrm{~L}^{-1}$, respectively. The red line represents the Michaelis-Menten fit. Table S1: Atomic charges of nitrogen and selenium according to NPA. Table S2: Donor-acceptor second order perturbation analysis. Table S3: DFT-computed energies for optimized geometries (in $\mathrm{kcal} / \mathrm{mol}$ ).

Author Contributions: Conceptualization, G.V.B., J.R. and A.L.B.; synthesis, spectral analysis, characterizations, and reagents/materials, G.V.B., L.B., R.F.S.C., F.A.R.B., S.S., H.G. and J.R.; GPX studies, W.C.E., D.N.O.S. and J.B.D.; DFT analysis, G.C.; writing-original draft, G.V.B. and J.R. writingreview and editing, G.V.B., J.R. and A.L.B. wrote the paper. All authors have read and agreed to the published version of the manuscript.

Funding: This research received no external funding.

Institutional Review Board Statement: Not Applicable.

Informed Consent Statement: Not Applicable.

Data Availability Statement: The data presented in this study are available on request from the corresponding author.

Acknowledgments: We gratefully acknowledge “Coordenação de Aperfeiçoamento de Pessoal de Nível Superior-CAPES" (Finance Code 001), “Conselho Nacional de Desenvolvimento Científico e Tecnológico-CNPq", "Instituto Nacional de Ciência e Tecnologia de Catálise em Sistemas Moleculares e Nanoestruturados-INCT-Catálise/CNPq/FAPESC", "Centro de Excelência para Pesquisa em Química Sustentável-CERSusChem" (grant 2014/50249-8), "Fundação de Amparo à Pesquisa do Estado de São Paulo-FAPESP", (grant 2014/50249-8) “GlaxoSmithKline—GSK" (grant 2014/502498). G.V.B. would like to acknowledge CNPq (429831/2018-8). J.R. would like to acknowledge CNPq (433896/2018-3 and 315399/2020-1). The authors acknowledge "Laboratório Central de Biologia Molecular Estrutural (CEBIME)" (UFSC-Brazil) for the HRMS analysis.

Conflicts of Interest: The authors declare no conflict of interest.

Sample Availability: Samples of the compounds can be checked with the author, G.V.B.

\section{References}

1. Shao, L.; Li, Y.; Lu, J.; Jiang, X. Recent progress in selenium-catalyzed organic reactions. Org. Chem. Front. 2019, 6, 2999-3041. [CrossRef]

2. Arora, A.; Sinhg, S.; Oswal, P.; Nautiyal, D.; Rao, G.K.; Kumar, S.; Kumar, A. Preformed molecular complexes of metals with organoselenium ligands: Syntheses and applications in catalysis. Coord. Chem. Rev. 2021, 438, 213885. [CrossRef]

3. Rafique, J.; Rampoin, D.S.; Azeredo, J.B.; Coelho, F.L.; Schneider, P.H.; Braga, A.L. Light-mediated seleno-functionalization of organic molecules: Recent advances. Chem. Rec. 2021. [CrossRef] [PubMed]

4. Li, Q.; Zhang, Y.; Chen, Z.; Pan, X.; Zhan, Z.; Zhu, J.; Zhu, X. Organoselenium chemistry-based polymer synthesis. Org. Chem. Front. 2020, 7, 2815-2841. [CrossRef]

5. Xiao, X.; Shao, Z.; Yu, L. A perspective of the engineering applications of carbon-based selenium-containing materials. Chin. Chem. Lett. 2021. [CrossRef]

6. Nogueria, C.W.; Barbos, N.V.; Rocha, J.B.T. Toxicology and pharmacology of synthetic organoselenium compounds: An update. Arch. Toxicol. 2021, 95, 1179-1226. [CrossRef] [PubMed]

7. Braga, A.L.; Rafique, J. Synthesis of biologically relevant small molecules containing selenium. Part A. Antioxidant compounds. In The Chemistry of Organic Selenium and Tellurium Compounds; Rappoport, Z., Ed.; Wiley: Chichester, UK, 2013; Volume 4, pp. 989-1052. 
8. Barbosa, N.V.; Nogueira, C.W.; Nogara, P.A.; Bem, A.F.; Aschner, M.; Rocha, J.B. Organoselenium compounds as mimics of selenoproteins and thiol modifier agentes. Metallomics 2017, 9, 1703-1734. [CrossRef]

9. Braga, A.L.; Rafique, J. Synthesis of biologically relevant small molecules containing selenium. Part C. Miscellaneous biological activities. In The Chemistry of Organic Selenium and Tellurium Compounds; Rappoport, Z., Ed.; Wiley: Chichester, UK, 2013; Volume 4, pp. 1119-1174.

10. Santi, C.; Bagnoli, L. Celebrating two centuries of research in selenium chemistry: State of the art and new prospective. Molecules 2017, 22, 2124. [CrossRef]

11. Mugesh, G.; Singh, H.B. Synthetic organoselenium compounds as antioxidants: Glutathione peroxidase activity. Chem. Soc. Rev. 2000, 29, 347-357. [CrossRef]

12. He, X.; Zhong, M.; Li, S.; Li, X.; Li, Y.; Li, Z.; Gao, Y.; Ding, F.; Wen, D.; Lei, Y.; et al. Synthesis and biological evaluation of organoselenium (NSAIDs-SeCN and $\mathrm{SeCF}_{3}$ ) derivatives as potential anticancer agents. Eur. J. Med. Chem. 2020, 208,112864 . [CrossRef] [PubMed]

13. He, X.; Nie, Y.; Zong, M.; Li, S.; Li, X.; Guo, Y.; Liu, Z.; Gao, Y.; Ding, F.; Wen, D.; et al. New organoselenides (NSAIDs-Se derivatives) as potential anticancer agents: Synthesis, biological evaluation and in silico calculations. Eur. J. Med. Chem. 2021, 218, 113384. [CrossRef]

14. Sabir, S.; Yu, T.T.; Kuppusamy Almohaywi, B.; Iskander, G.; Das, T.; Willcox MD, P.; Black, D.S.; Kumar, N. Novel seleno- and thio-urea containing dihydropyrrol-2-one analogues as antibacterial agents. Antibiotics 2021, 10, 321. [CrossRef] [PubMed]

15. Ali, W.; Benedetti, R.; Handzlik, J.; Zwergel Battisetlli, C. The innovative potential of selenium-containing agents for fighting cancer and viral infections. Drug Discov. Today 2021, 26, 256-263. [CrossRef] [PubMed]

16. Almeida, G.M.; Rafique, J.; Saba, S.; Siminski, T.; Mota NS, R.S.; Filho, D.W.; Braga, A.L.; Pedrosa, R.C.; Ourique, F. Novel selenylated imidazo[1,2-a]pyridines for breast cancer chemotherapy: Inhibition of cell proliferation by Akt-mediated regulation, DNA cleavage and apoptosis. Biochem. Biophys. Res. Commun. 2018, 503, 1291-1297. [CrossRef] [PubMed]

17. Chen, Z.; Lai, H.; Hou, L.; Chen, T. Rational design and action mechanisms of chemically innovative organoselenium in cancer therapy. Chem. Commun. 2020, 56, 179-196. [CrossRef]

18. Santos, D.C.; Rafique, J.; Saba, S.; Almeida, G.M.; Siminski, T.; Padua, C.; Filho, D.W.; Zamoner, A.; Braga, A.L.; Pedrosa, R.C.; et al. Apoptosis oxidative damage-mediated and antiproliferative effect of selenylated imidazo[1,2-a]pyridines on hepatocellular carcinoma HepG2 cells and in vivo. J. Biochem. Mol. Toxicol. 2021, 35, e22663. [CrossRef]

19. Spengler, G.; Gjdacs, M.; Marc, M.A.; Dominguez-Alvarez, E.; Sanmartin, C. Organoselenium compounds as novel adjuvants of chemotherapy drugs-A promising approach to fight cancer drug resistance. Molecules 2019, 24, 336. [CrossRef]

20. Kumawat, A.; Raheem, S.; Ali, F.; Dar, T.A.; Chakrabarty, S.; Rizvi, M.A. Organoselenium compounds as acetylcholinesterase inhibitors: Evidence and mechanism of mixed inhibition. J. Phys. Chem. B 2021, 125, 1531-1541. [CrossRef]

21. Rodrigures, J.; Saba, S.; Joussef, A.C.; Rafique, J.; Braga, A.L. $\mathrm{KIO}_{3}$-catalyzed C( $\left.\mathrm{sp}^{2}\right)$-H bond selenylation/sulfenylation of (hetero)arenes: Synthesis of chalcogenated (hetero)arenes and their evaluation for anti-Alzheimer activity. Asian J. Org. Chem. 2018, 7, 1819-1824. [CrossRef]

22. Kepp, K.P. Bioinorganic chemistry of Alzheimer's disease. Chem. Rev. 2012, 112, 5193-5239. [CrossRef] [PubMed]

23. Scheide, M.R.; Schneider, A.R.; Jardin GA, M.; Martins, G.M.; Durigon, D.C.; Saba, S.; Rafique, J.; Braga, A.L. Electrochemical synthesis of selenyl-dihydrofurans via anodic selenofunctionalization of allyl-naphthol/phenol derivatives and their antiAlzheimer activity. Org. Biomol. Chem. 2020, 18, 4916-4921. [CrossRef]

24. Wang, B.; Wang, Z.; Chen, H.; Lu, C.-J.; Li, X. Synthesis and evaluation of 8-hydroxyquinolin derivatives substituted with (benzo[d][1,2]selenazol-3(2H)-one) as effective inhibitor of metal-induced $A \beta$ aggregation and antioxidant. Bioorg. Med. Chem. 2016, 24, 4741-4749. [CrossRef]

25. Veloso, I.C.; Delangara, E.; Machado, A.E.; Braga, S.P.; Rosa, G.K.; Bem, A.F.; Rafique, J.; Saba, S.; Trindade, R.N.; Galetto, F.Z.; et al. A selanylimidazopyridine (3-SePh-IP) reverses the prodepressant- and anxiogenic-like effects of a high-fat/high-fructose diet in mice. J. Pharm. Pharmacol. 2021, 73, 673-681. [CrossRef]

26. Gülçin, I.; Trofimov, B.; Kaya, R.; Taslimi, P.; Sobenina, L.; Schmidt, E.; Petrova, O.; Malysheva, S.; Gusarova, N.; Farzaliyev, V.; et al. Synthesis of nitrogen, phosphorus, selenium and sulfur-containing heterocyclic compounds-Determination of their carbonic anhydrase, acetylcholinesterase, butyrylcholinesterase and $\alpha$-glycosidase inhibition properties. Bioorg. Chem. 2021, 103, 104171. [CrossRef]

27. Martín-Escolano, R.; Etxebeste-Mitxeltorena, M.; Martín-Escolano, J.; Plano, D.; Rosales, M.J.; Espuelas, S.; Moreno, E.; SánchezMoreno, M.; Sanmartín, C.; Marín, C. Selenium Derivatives as Promising Therapy for Chagas Disease: In Vitro and In Vivo Studies. ACS Infect. Dis. 2021. [CrossRef]

28. Galant, L.S.; Rafique, J.; Braga, A.L.; Braga, F.C.; Saba, S.; Radi, R.; Rocha JB, T.; Santi CMonsalve, M.; Farina, M.; Bem, A.F. The thiol-modifier effects of organoselenium compounds and their cytoprotective actions in neuronal cells. Neurochem. Res. 2021, 46, 120-130. [CrossRef]

29. Jin, Z.; Du, X.; Xu, Y.; Deng, Y.; Liu, M.; Zhao, Y.; Zhang, B.; Li, X.; Zhang, L.; Peng, C.; et al. Structure of Mpro from COVID-19 virus and discovery of its inhibitors. Nature 2020, 582, 289-293. [CrossRef] [PubMed]

30. Sies, H.; Parnham, M.J. Potential therapeutic use of ebselen for COVID-19 and other respiratory viral infections. Free Radic. Biol. Med. 2020, 156, 107-112. [CrossRef] 
31. Sun, L.-Y.; Chen, C.; Su, J.; Li, J.-Q.; Jiang, Z.; Gao, H.; Ching, J.-Z.; Ding, H.-H.; Zhai, L.; Yang, K.-W. Ebsulfur and Ebselen as highly potent scaffolds for the development of potential SARS-CoV-2 antivirals. Bioorg. Chem. 2021, 112, 104889. [CrossRef] [PubMed]

32. Masuda, R.; Kimura, R.; Karasaki, T.; Sase, S.; Goto, K. Modeling the catalytic cycle of glutathione peroxidase by nuclear magnetic resonance spectroscopic analysis of selenocysteine selenenic acids. J. Am. Chem. Soc. 2021, 143, 6345-6350. [CrossRef]

33. Bortoli, M.; Madabeni, A.; Nogara, P.A.; Omage, F.B.; Ribaudo, G.; Zeppliil, D.; Rocha JB, T.; Orian, L. Chalcogen-nitrogen bond: Insights into a key chemical motif. Catalysts 2020, 11, 114. [CrossRef]

34. Sudati, J.H.; Nogara, P.A.; Saraiva, R.A.; Wagner, C.; Alberto, A.E.; Braga, A.L.; Fachinetto, R.; Piquini, P.C.; Rocha, J.B.T. Diselenoamino acid derivatives as GPx mimics and as substrates of TrxR: In vitro and in silico studies. Org. Biomol. Chem. 2018, 16, 3777-3787. [CrossRef] [PubMed]

35. Rafique, J.; Saba, S.; Canto RF, S.; Frizon TE, A.; Hassan, W.; Waczuk, E.P.; Jan, M.; Back, D.F.; Rocha JB, T.; Braga, A.L. Synthesis and biological evaluation of 2-picolylamide-based diselenides with non-bonded interactions. Molecules 2015, 20, 10095-10109. [CrossRef] [PubMed]

36. Collins, C.A.; Fry, F.H.; Holme, A.L.; Yiakouvaki, A.; Al-Qenaei, A.; Pourzand, C.; Jacob, C. Towards multifunctional antioxidants: Synthesis, electrochemistry, in vitro and cell culture evaluation of compounds with ligand/catalytic properties. Org. Biomol. Chem. 2005, 3, 1541-1546. [CrossRef]

37. Nowak, P.; Saluk-Juszczak, J.; Olas, B.; Kolodziejczyk, J.; Wachowics, B. The protective effects of selenoorganic compounds against peroxynitrite-induced changes in plasma proteins and lipids. Cell. Mol. Biol. Lett. 2006, 11, 1-11. [CrossRef] [PubMed]

38. Saluk, J.; Bijak, M.; Nowak, P.; Wachowicz, B. Evaluating the antioxidative activity of diselenide containing compounds in human blood. Bioorg. Chem. 2013, 50, 26-33. [CrossRef] [PubMed]

39. Kloc, K.; Mlochowski, L.; Osajda, K.; Sypeer, L.; Wójtowics, H. New heterocyclic selenenamides: 1,2,4-benzoselenadiazin-3(4H)ones and 1,3,2-benzodiselenazoles. Tetrahedron Lett. 2002, 43, 4071-4074. [CrossRef]

40. Viglianisi, C.; Simone, L.; Menichetti, S. Copper-Mediated One-Pot Transformation of 2-N-Sulfonyl- aminoaryl Diselenides into Benzo[b][1,4]selenazines. Adv. Synth. Catal. 2012, 354, 77-82. [CrossRef]

41. Radatz, C.S.; Alves, D.; Schneider, P.H. Direct synthesis of 2-aryl-1,3-benzoselenazoles by reaction of bis(2-aminophenyl) diselenides with aryl aldehydes using sodium metabisulfite. Tetrahedron 2013, 69, 1316-1321. [CrossRef]

42. Deobald, A.M.; Camargo LR, S.; Hörner, M.; Rodrigues OE, D.; Alves, D.; Braga, A.L. Synthesis of arylseleno-1,2,3-triazoles via copper-catalyzed 1,3-dipolar cycloaddition of azido arylselenides with alkynes. Synthesis 2011, 15, 2397-2406.

43. Frizon TE, A.; Cararo, J.H.; Saba, S.; Dal-Pont, G.C.; Michels, M.; Braga, H.C.; Pimentel, T.; Dal-Pizzol, F.; Valvassori, S.S.; Rafique, J. Synthesis of novel selenocyanates and evaluation of their effect in cultured mouse neurons submitted to oxidative stress. Oxid. Med. Cell. Longev. 2020, 5417024. [CrossRef]

44. Scheide, M.R.; Peterle, M.M.; Saba, S.; Neto JS, S.; Lenz, G.F.; Cezar, R.D.; Felix, J.F.; Botteselle, G.V.; Schneider, R.; Rafique, J.; et al. Borophosphate glass as an active media for $\mathrm{CuO}$ nanoparticle growth: An efficient catalyst for selenylation of oxadiazoles and application in redox reactions. Sci. Rep. 2020, 10, 15233. [CrossRef]

45. Rafique, J.; Farias, G.; Saba, S.; Zapp, E.; Bellettini, I.C.; Salla, C.A.M.; Bechtold, I.H.; Scheide, M.R.; Neto JS, S.; Souza, D.M., Jr.; et al. Selenylated-oxadiazoles as promising DNA intercalators: Synthesis, electronic structure, DNA interaction and cleavage. Dyes Pigm. 2020, 180, 108519. [CrossRef]

46. Peterle, M.M.; Scheide, M.R.; Silva, L.T.; Saba, S.; Rafique, J.; Braga, A.L. Copper-catalyzed three-component reaction of oxadiazoles, elemental Se/S and aryl iodides: Synthesis of chalcogenyl (Se/S)-oxadiazoles. Chemitryselect 2018, 3, 13191-13196. [CrossRef]

47. Silva, L.T.; Azerefo, J.B.; Saba, S.; Rafique, J.; Bortoluzzi, A.J.; Braga, A.L. Solvent- and metal-free chalcogenation of bicyclic arenes Using $\mathrm{I}_{2}$ /DMSO as non-metallic catalytic system. Eur. J. Org. Chem. 2017, 32, 4740-4748. [CrossRef]

48. Rafique, J.; Saba, S.; Frizon TE, A.; Braga, A.L. $\mathrm{Fe}_{3} \mathrm{O}_{4}$ nanoparticles: A robust and magnetically recoverable catalyst for direct C-H bond selenylation and sulfenylation of benzothiazoles. Chemsitryselect 2018, 3, 328-334. [CrossRef]

49. Rocah MS, T.; Rafique, J.; Saba Azerdo, J.B.; Back, D.; Godoi, M.; Braga, A.L. Regioselective hydrothiolation of terminal acetylene catalyzed by magnetite $\left(\mathrm{Fe}_{3} \mathrm{O}_{4}\right)$ nanoparticles. Synth. Commun. 2017, 47, 291-298. [CrossRef]

50. Rafique, J.; Saba, S.; Rosario, A.R.; Zeni, G.; Braga, A.L. $\mathrm{K}_{2} \mathrm{CO}_{3}$-mediated, direct $\mathrm{C}-\mathrm{H}$ bond selenation and thiolation of 1,3,4-oxadiazoles in the absence of metal catalyst: An eco-friendly approach. RSC Adv. 2014, 4, 51648-51652. [CrossRef]

51. Menichetti, S.; Capperucci Tanini, D.; Braga ALBotteselle, G.V.; Viglianisi, C. A one-pot access to benzo[b][1,4]selenazines from 2-aminoaryl diselenides. Euro. J. Org. Chem. 2016, 18, 3097-3102. [CrossRef]

52. Sharma, U.; Verma, P.K.; Kumar, N.; Kumar, V.; Bala, M.; Singh, B. Phosphane-free green protocol for selective nitro reduction with an iron-based catalyst. Chem. Eur. J. 2011, 17, 5903-5907. [CrossRef]

53. Iwaoka, M.; Tomoda, S. A model study on the effect of an amino group on the antioxidant activity of glutathione peroxidase. $J$. Am. Chem. Soc. 1994, 116, 2557-2561. [CrossRef]

54. Neese, F. Software update: The ORCA program system, version 4.0. Wiley Interdiscip. Rev. Comput. Mol. Sci. 2017, 8, e1327. [CrossRef] 
55. Grimme, S.; Antony, J.; Ehrlich, S.; Krieg, H. A consistent and accurate ab initio parametrization of density functional dispersion correction (DFT-D) for the 94 elements H-Pu. J. Chem. Phys. 2010, 132, 154104. [CrossRef] [PubMed]

56. Glendening, E.D.; Badenhoop, J.K.; Reed, A.E.; Carpenter, J.E.; Bohmann, J.A.; Morales, C.M.; Landis, C.R.; Weinhold, F. NBO 6.0; Theoretical Chemistry Institute, University of Wisconsin: Madison, WI, USA, 2013; Available online: http://nbo6.chem.wisc.edu/ (accessed on 12 July 2021). 